JÓZEF SZYMAŃSKI

\title{
ARCHIWUM I BIBLIOTEKA PARAFIALNA W WOJNICZU
}

W organizacji diecezji krakowskiej oraz w jej życiu kościelnym znaczną rolę odegrał Wojnicz. Również w powstałej w wyniku rozbiorów diecezji tarmowskiej ${ }^{1}$ spełniał on $\mathrm{i}$ do dziś pełni znaczną rolę. Już w drugiej połowie XIII w. istniała tutaj siedziba dekanatu wojnickiego?, co też nieprzerwanie trwa do dnia dzisiejszego. W r. 1465 doszło w Wojniczu do erekcji prepozytury parafialnej, która w dalszym rozwoju historyczno-prawnym dała początek kolegiacie $z$ dosyć liczną kapitułą". W r. 1751 został erygowany archidiakonat wojnicki ${ }^{4}$. Niestety w r. 1795 kolegiata została zniesiona przez rząd austriacki ${ }^{5}$.

Dzięki tej roli Wojnicza, przy kościele kolegiackim św. Wawrzyńca powstał znaczny zasób archiwalny oraz stosunkowo bogaty zbiór biblioteczny, najzasobniejszy $w$ starodruki na terenie powiatu brzeskiego, do którego należy Wojnicz. Historia tych zbiorów będzie przedmiotem naszego artykułu, który $\mathrm{w}$ swej części informacyjnej poda szereg wiadomości o ich zawartości. Oba zbiory bogactwo swe zawdzięczają tutejszej kapitule kolegiackiej, co też będzie podkreślone w toku dalszych wywodów.

Problem zorganizowania archiwum kapituły kolegiackiej w Wojniczu po raz pierwszy pojawia się na posiedzeniu tejże kapituły dnia 16 II $1666 \mathrm{r}$. Wtedy to, na skutek zaleceń powizytacyjnych biskupa Mi-

1 Ks. B. K u mor: Dzieje polityczno-geograficzne diecezji tarnowskiej. Lublin 1958 s. $30 \mathrm{nn}$.

2 J. Szymán ski: Dekanat wojnicki w świetle niektórych uwag o organizacji dekanalnej diecezji krakowskiej w XIII-XVI w. „Rocz-i teol.-kan." T. 8: 1961 z. 1.

3 T e nż e: Początki kolegiaty św. Wawrzyńca w Wojniczu. Praca złożona w Redakeji „Prawa Kanoniczneg.o”.

4 Te nże: Powstanie i organizacja archidiakonatu wojnickiego. „Rocz-i teol.kan." T. 5: 1958 z. 4 s. $83-102$.

s $\mathrm{Na}$ podstawie dekretu ces. Józefa II z r. 1785, który zalecał znoszenie kolegiat, dnia $24 \mathrm{~V} 1786 \mathrm{r}$, ukazało się rozporzadzenie zamieniające prebende prepozyta w banef cjum proboszczowskie, z równoczesnym ogłoszeniem lkonkursu na objęcie go po śm:erei ostatniego prepozyta wojnickiego Jana Duwalla. Prothocolla Ecclesiae Collegiatae Voyniciensis. T. II s. 66. (Sygn. L/4/7/333). Archiwum Parafialne w Wojniczu (dalej cytuje APW). Dochody innych prebend zostały przejęte przez fundusz religijny. 
kołaja Oborskiego sufragana krakowskiego, postanowiono założyć księgę protokółów posiedzień, sprawić pieczęć kapitulną i przechowywać akta w specjalnie na ten cel przeznaczonej skrzyni ". Uchwałę tę. można zrozumieć jako formalne założenie archiwum. Realizacja jej napotkała jednak na trudności, skoro skrzynię ufundował dopiero w r. 1674 kusiosz Jagielski ${ }^{7}$. Charakterysiycznym jest, iż notariusz kapituły zapisał w związku z tym, że ma się w niej przechowywać wszystkie dokumenty dotyczące kapituly i kościoła kolegiackiego. Już w r. 1685 kapituła podjęła uchwałę, że wszystkie nowe akiy erekcyjne prebend, fundacji, aniwersarzy itp. wraz $\mathrm{z}$ całą związaną z rimi dokumentacją mają być składane $\mathrm{w}$ archiwum a nie jak dotychczas znajdować się na przechowaniu u zainteresowanych nimi prałatów i kanoników ${ }^{8}$. Uchwała ta została podjęta $w$ specjalnej atmosferze. Ówczesny bowiem prepozyt kapituły Stefan Eodziński ${ }^{9}$ od szeregu lat dążył do rewindykacji różnych praw i dochodów prepozytury. W tym celu zamierzał zgromadzić jak najwięcej argumentów prawnych $w$ formie dokumentów. Dlatego też w r. 1686 prałaci i kanonicy podjęli uchwałę, aby wszcząc starania o skompletowanie wszystkich dokumentów dotyczących przeszłości kościoła kolegiackiego i jego kapituły ${ }^{10}$.

Sprawę archiwum potraktowała kapituła naprawdę poważnie dopiero w r. 1703, kiedy to nałożyła na swego notariusza obowiązek skompletowania archiwaliów i powierzyła mu troskę o te bezcenne według jej mniemania akta. Kanonikom zwlekającym z oddaniem przechowywanych lub wypożyczonych przez nich dokumentów zagrożono nawet karami pieniężnymi ${ }^{11}$. Już $\mathrm{w}$ tym czasie usiłowano $\mathrm{w}$ archiwum wprowa* dzić jakąś segregację archiwaliów i w jakiś logiczny sposób uporządkować je, skoro notariusz kapitulny, pisząc o pewnym dokumencie, określa go krótko jako dokument nr $18^{12}$.

Realizacja uchwały podjętej w r. 1703 napotykała jednak na coraz to nowe trudności, skoro w r. 1707 kapituła ponawia ją i postanawia, aby do archiwum były dwa klucze. Dotychczas bowiem klucz miał jedýnie kustosz a ten wypożyczył go prepozytowi, który z kolei zaprze-

16 Acta Capituli Collegiatae Voyniciensis. T. I s. 1. (APW Sygn. L/1/1/327. Dalej cytuję jako ACV.

7 ACV. T. I s. 15.

8 ACV. T. I s. 25.

9 Stefan Eodziński herbu Radwan (1675-1689) oficjał pilecki i proboszcz w Szczekocinach, autor panegiryku na cześć króla Michała Wiśniowieckiego.

10 ACV. T, I s, 26.

11 ACV. T. I s. $44,45$.

12 ACV. T. I s. 45. 
paścił cały szereg dokumentów. Odtąd więc miały być zapewne dwa różne klucże i $\mathrm{z}$ nich jeden oddano kustoszowi a drugi notariuszowi kapituły ${ }^{13}$. Chodziło kapitule o dokładniejszą kontrolę sposobu korzystania z zasobu archiwalnego a przez to o zabezpieczenie się przed dotkliwymi w skutkach stratami.

Odtąd też sprawa archiwum kapitulnego została właściwie rozwiązana. Nie napotykamy już bowiem na uchwały, które miałyby w jakiś sposób organizować archiwum. Pojawiają się natomiast notatki wskazujące na normalne jego funkcjonowanie.

Dokumenty $\mathrm{z}$ archiwum wypożyczano zainteresowanym osobom za specjalnym rewersem. Trzy takie rewersy dochowaly się do dziś. Mianowicie na okładce drugiego tomu protokółów posiedzeń kapitulnych zanotowano udostępnienie dokumentów w r. 1718, 1726 i 1729. Wszystkie trzy rewersy wskazują na zwrot wydanych akt. Że kapituła w tym czasie troskliwie pilnowała całości swego archiwum, wskazuje postępowanie jej w stosunku do scholastyka Garlickiego, który w r. 1728 wypożyczył dokumenty dotyczące jego prebendy. Ponieważ po roku ich nie zwrócił, kapituła zabroniła $w$ ogóle wydawania $z$ archiwum oryginałów, polecając notariuszowi sporządzanie jedynie uwierzytelnionych przez niego na koszt zainteresowanego odpisów ${ }^{14}$. Kiedy jednak Garlicki $w$ dalszym ciągu nie zwracał dokumentów, kapituła nałożyła w r. 1731 sekwestr na jego dochody. Sekwestr trwał aż do r. 1736, w którym scholastyk zdecydował się dokumenty oddać ${ }^{15}$. Podobne wypadki, jakkolwiek mniej drastyczne, miały miejsce z innymi członkami kapituły w latach 1715 i $1724^{16}$.

Równocześnie kapituła prowadziła nadal akcje zbierania rozproszo. nych dokumentów. Wielce się w tym przysłużył kanonik Andrzej Gorzewski, notariusz publiczny, proboszcz w Siemiechowie i dziekan foralny wojnicki. On to w r. 1707 przystąpił do ostatecznego uporządkowania archiwum, sam sporządził odpisy całego szeregu dokumentów a ważniejsze wpisał do ksiąg posiedzeń kapitulnych ${ }^{17}$.

Sprawą archiwum kapitulnego zajął się także w czasie wizytacji kanonicznej kolegiaty i kapituły w r. 1749 Andrzej Stanisław Załuski biskup krakowski, który polecił skompletować dokumenty w postaci od-

ACV. T. I s, 60.

ACV. T. II s. 94. (Sygn. L/1/2/328).

ACV. T. II s. 94, 96, 104.

ACV. T. II s, 18,70 .

7 ACV. T. I s. 59 ; t. II s. $5,11,43,66$, 
pisów potwierdzonych bądż przez notariusza publicznego bądź przez prepozyta kapituły ${ }^{18}$. Rezultatem tego zarządzenia była kwerenda przeprowadzona $w$ archiwum krakowskim przez notariuszy Dominika Krzyżańskiego i Jana Rafałowicza zakończona w r. 1753, która przyniosła około 150 odpisów różnych dokumentów, przeważnie z ksiąg oficjalskich, przechowywanych obecnie w Archiwum Kurii Metropolitalnej w Krakowie ${ }^{19}$. W ten sposób archiwum zgromadziło niemal wszystkie ważniejsze dokumenty odnoszące się do praw i uposażenia kolegiaty i kapituły.

Lata po 1772 r. przyniosły raczej dewastację zasobu archiwalnego. Przede wszystkim rząd austriacki swoimi zarządzeniami z lat 1775-1784, polecającymi przesłać do urzędów cyrkularnych i gubernium dokumenty dotyczące majątku kościelnego ${ }^{* 0}$, pozbawił archiwum wojnickie niejednego cennego dokumentu. Wprawdzie są dowody na to, że ówczesny prepozyt kapituły Jan Duwall pilnował, aby wysyłać tylko kopie, tym niemniej szereg oryginałów już wtedy zaginęło. Wartość i ilość strat trudno ustalić, gdyż dotychczas nie było żadnego inwentarza archiwum. Pierwszy inwentarz pochodzi z r, 1781. Trudno jednak nazwać go inwentarzem w pełnym tego słowa znaczeniu, albowiem został sporządzony przez ówczesnego prokuratora kapituły wojnickiej, scholastyka Szymona Banaczkowskiego w celu uzasadnienia pewnych praw majątkowych kolegiaty. Zawiera on wykaz 21 dokumentów, przeważnie z XVIII w. ${ }^{21}$

Podobny charakter ma wykaz prepozyta Jana Duwalla z r. 1784, w którym tenże zawiadamia cyrkuł $\mathrm{w}$ Bochni o wysłaniu inwentarza z r. 1781 oraz pięciu kopii, a mianowicie: dokumentu erekcyjnego kolegiaty z r. 1465, wyciągu z Liber Beneficiorum Długosza, dekretu Jana Kazimierza z r. 1669 o prawach prepozytury, oryginału aktu Zygmunta III Wazy z r. 1628 wcielającego parafię w Jadownikach do uposażenia kolegium mansjonariuszy wojnickich oraz relację Szymona Banaczkowskiego z procesu lwowskiego o dziesięciny należne scholasterii ${ }^{22}$.

Pierwszy inwentarz $w$ pełnym tego słowa znaczeniu został sporzadzony dopiero w r. 1801 przez prepozyta Floriana Wąsowicza. Wylicza on $\mathrm{w}$ nim 55 pozycji, w tym 7 dokumentów z XV i 11 z XVI wieku.

18 Actus visitationis 1749. Sygn. L/2/4/330. (APW).

19 ACV. T. II s. 126.

20 Zob, Ks. B. K u m o r: Nieznane falsyfikaty St. Morawskiego. „Małop. Studia hist." 2: 1959 z. $2 / 3$ s. 115.

21 Archiwum Diecezjalne w Tarnowie. Akta par. Wojnicz. (Dalej cytuję ADT). $22 \mathrm{ADT}$. 
Wymieniony tutaj inwentarz biblioteki kapitulnej sporządzony w r. 1776, niestety, nie dochował się ${ }^{23}$. Pełny inwentarz archiwum sporządził w r. 1847 miejscowy wikariusz Andrzej Kutrzeba ${ }^{24}$. W oparciu o niégo prepozyt Paweł Białobrzeski — w związku z przekazaniem zasobów archiwalnych, za wyjątkiem akt powstałych w XIX w., Kurii Biskupiej w Tarnowie - przygotował w roku następnym (1848) nowy spis archiwaliów. Obydwa inwentarze obejmują po 110 pozycji, wśród nich 7 dokumentów z XV i 11 z XVI stulecia, a więc w takiej samej ilości, jaką wykazuje inwentarz z r. $1801^{25}$. Jak można wywnioskować na podstawie inwentarza z r. 1848, w Archiwum Diecezjalnym w Tarnowie do grupy dokumentów wojnickich przybyło później jedynie 16 fascykułów z XVII i XVIII w.

Inwentarze z lat 1847 i 1848 nie obejmowały jednak wszystkich akt przechowywanych w archiwum, albowiem prepozyt Błażej Gwiazdoń, sporządzający ok. $1868 \mathrm{r}$. nowy inwentarz, wykazał w nim jeszcze dwie księgi oprawne zawierające dokumenty z XVIII w., dwa tomy protokołów posiedzeń kapituły i kilkanaście ksiąg metrycznych, wśród nich jedna z XVII i trzy z XVIII. w. Co najważniejsze, że wylicza on Libri documentorum z r. 1703 i 1728, o których dotąd niczego nie było wiadomo ani też do tej pory nie udało się ich odnaleźć. Prawdopodobnie oba kopiariusze zostały sporządzone przez wspomnianego kanonika Gorzewskiego. Strata ich jest tym dotkliwsza, że Gorzewski był staranny $\mathrm{w}$ kopiowaniu dokumentów ${ }^{\mathbf{2 6}}$.

Po inwentarzu Gwiazdonia nie sporządzono już w latach następnych inwentarza nowego, mimo iż akt $\mathrm{w}$ archiwum ciągle przybywało, tak nowych jak i dawniejszych od czasu do czasu odnajdujących się.

Ostatnia inwentaryzacja została przeprowadzona w r. 1954. Objęla ona 437 pozycji. Całość archiwum została podzielona na piętnaście dzialów i dziewięćdziesiąt cztery sekcje. Każda sekcja obejmuje całość dostępnej dokumentacji pewnego zagadnienia. Tak np. w dziale K (kościoły, kaplice, cmentarze) znajduje się sekcja 23 (kaplica loretańska), która zawiera 10 dokumentów odnoszących się do kaplicy Matki Boskiej Loretańskiej w Wojniczu przy ulicy Loretańskiej. Jedynie w dziale C, obejmującym grupę akt odnoszących się do dziejów kolegiaty i kapituły, nie wprowadzono podziału na sekcje.

\footnotetext{
$23 \quad$ ADT.

24 Sygn. A/3/3/235. (APW).

25 ADT.

20 Sygn. A/3/9/341. (APW).
} 
Archiwum wojnickie nie posiada materiałów o wartości ogólnej, za wyjątkiem może niektórych pozycji z przełomu XVIII i XIX w., niemniej jednak mieści w sobie ważne źródła dla przeszłości samego miasla Wojnicza. Aby zapoznać się z jego zawartością, przejdziemy po kolei poszczególne działy.

Najbardziej interesującym jest dział $L_{\text {, }}$ obejmujący księgi archiwalne. Mamy tutaj dwa tomy protokołów posiedzeń kapituły $\mathrm{z}$ lat 1666-1757, liczące razem 203 zapisane strony in folio. Jest to główne źródło do poznania przeszłości kapituly kolegiackiej. Dalej idą dwa dekrely reformacyjne kolegiaty i kapituly: z r. 1725 biskupa Konstantego Szaniawskiego, obejmujący również statuty tejże kapituły oraz z r. 1749 biskupa Andrzeja Stanisława Załuskiego. Z r. 1773 pochodzi akt erekcyjny prałatury kanclerza a z r. 1669 kanonii fundi Śliwki II. $Z$ lat 1780-1833 pochodzą cztery tomy „Prothocolla Ecclesiae Collegiatae Voyniciensis", które na 1138 stronicach in folio zawierają wszystkie niemal ówczesne rozporządzenia cyrkułów, gubernium lwowskiego, konsystorzów generalnych w Tarnowie i Starym Sączu oraz kurii diecezjainych w Tarnowie i Bochni odnoszące się do spraw kościelnych.

Ciekawym żródłem do poznania dziejów samej parafii jest 13 tomów ogłoszeń z ambony. Są to teksty o charakterze administracyjno-organizacyjnym i odnoszą się do lat 1828-1952. Lukę stanowią tutaj lata 1893-1916. Ogłoszenia obejmują przeszło 1500 stron zapisanych in folio. $\mathrm{Z}$ innych dziewiętnastowiecznych ksiąg wiele ciekawego materiału zawierają dwie księgi wydatków domu ubogich 1833-1883, wykaz czynności duszpasterskich 1832-1888, iura stolae 1860-1889 oraz księgi protokołów posiedzeń i czynności takich organizacji kościelnych jak komitetu kościelnego, kółka adoracji miesięcznych, szkaplerza, III zakonu św. Franciszka, bractwa różańcowego, towarzystwa misyjnego św. Franciszka Ksawerego, apostolstwa Serca Jezusowego, towarzystwa wstrzemiężliwości itp. - w sumie 17 tomów obejmujących około 2000 stron zapisanych przeważnie in folio. Działalność administracyjną miejscowego urzędu parafialnego ilustruje 7 tomów dziennika podawczego z lat 1832-1929.

Ważnym żródłem do poznania przeszłości parafii w XIX w. jest "Liber memorabilium", niestety tylko za lata 1832-1885. Dalej "Status animarum" z r. 1832, żródło demograficzne, nie bez znaczenia dla badan socjologicznych. 
Odrębny dział archiwum stanowią księgi metrykalne oraz im pokrewne. Już w r. 1594 istniały w Wojniczu jakieś księgi metrykalne ${ }^{2.7}$ lecz niestety nie dochowały się. Są natomiast metryki ochrzczonycil, zmarłych i zaślubionych $\mathrm{z}$ lat $1675-1712$ obejmujące około 300 stron in folio. Po r, 1712 metryk prawdopodobnie nie spisywano, skoro w r. 1731 biskup Kunicki sufragan krakowski w czasie wizytacji kolegiaty nakazywał prowadzenie ksiąg metrykalnych ${ }^{28}$. Nowe księgi zalożył dopiero Jan Duwall w r. 1757. Są to trzy tomy (dudki), liczące w sımie około 600 stron i obejmujące lata 1757-1784. W r. 1784 założono według nakazanych wzorów austriackich nowe księgi metrykalne, oddzielne dla każdej gminy wchodzącej w skład parafii. Do r. 1939 zapisano ich 32 tomy. Z działem ksiąg metrykalnych łączą się księgi zapowiedzi o zamierzonych małżeństwach. Zaczęto je prowadzić od r. 1828; do r. 1939 powstało ich 8 tomów.

Inne działy zawierają akta $\mathrm{w}$ postaci fascykułów i odnoszą się wỵlạcznie do XIX i XX wieku. I tak w dziale A (archiwum) zinwentaryzowano 9 fascykułów, które ilustrują dzieje zbioru oraz kilka przeprowadzonych w nim kwerend. Dział K zawiera akta odnoszące się do kośs ciołów wojnickich, kaplic i cmentarzy. Obejmuje on największą część archiwum, bo 122 fascykuły. Dział $\mathrm{P}$ zawiera akta odnoszące się do księży pracujących w Wojniczu i liczy 15 fascykułów. Są to szkice kazań, testamenty, własnoręczne życiorysy itp.

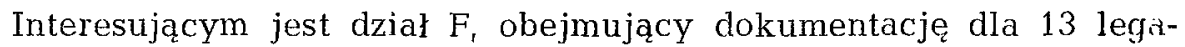
tów pobożnych z XIX i XX w. Liczy on 62 fascykuły ilustrujące korespondencję na temat legatów z ordynariuszem, namiestnictwem, bankami itp. Dział B stanowi dokumentację beneficjum i jego majątku i obejmuje 67 fascykułów dotyczących fasji, służebności, kongruy, alienacji i dzierżaw, podatków, asekuracji, procesów oraz konserwacji budynków beneficjalnych.

Jak już wspomniano, dział C obejmuje dokumenty sprzed $1800 \mathrm{r}$. A więc są tu: z $1603 \mathrm{r}$. proces scholastyka ze starostą, z 1622 - alienacja ogrodu przez mieszczankę Zgłobiną na rzecz altarii św. Anny, z 1682 - testament mieszczanki Matlickiej, z 1690 - redukcja obowiązków mszalnych altarii św. Anny przez Kongregację Interpretacji Soboru Trydenckiego, z 1691 - ekskomunika na starostę wojnickiego, z 1695 -legat 2000 złp dla altarii św. Krzyża, z 1703 -- proces wikarych katedry

27 Archiwum Kurii Metrop. w Krakowie. Acta visitationis Radzivilianae exterior. Nr 7 k. 78 .

28 Tamże Acta visitationis. $\mathrm{Nr} 61 \mathrm{k}, 947$. 
krakowskiej o dom w Krakowie, jedyny dokument obcy w tym dziale, z 1714 - legat Śliwskiego w wysokości 4000 złp dla nowej kanonii fundi Sliwki IV, z 1715 - ekskomunika na magistral wojnicki, z 1737 - fundusz 1000 złp dla arcybractwa różańcowego (kopia), z 1766 - fundusz 1000 złp dla szkoły kolegiackiej dany przez mieszczanina Morawickiego (kopia), z 1773 - akt konsekracji kolegiaty przez biskupa Ignacego Kajetana Soltyka. Ponadto są dwa kopiarze: jeden obejmuje 9 dokumentów z XVI-XVII w., dotyczących altarii św. Anny i złączonego z nią kościoła św. Leonarda; drugi zawiera odpis 5 dokumentów z XVII i XVIII. w. dotyczących kolegium mansjonariuszy, domu ubogich oraz bractw Trójcy św. i różańcowego.

Dział O zawiera dokumenty obce, dotyczące parafii Niedźwied $z_{,}$ Dębno i rodziny Zaczków. Dział U obejmuje sprawy domu ubogich a dział S księgi stowarzyszeń religijnych, które zostały już omówione razem $\mathrm{z}$ zawartością działu $\mathrm{L}$.

Jak z tego wynika, archiwum wojnickie nie posiada wprawdzie jakichś nadzwyczaj ciekawych i ważnych dokumentów, ale bez ich znajomości nie można obyć się przy oditwarzaniu przeszłości parafii, przynajmniej od połowy XVII w. Zawierają natomiast ważne żródła dla XIX-wiecznej przeszłości i ciekawy materiał nie tylko dla historyka ale i dla socjologa oraz demografa. Można tutaj również natrafić na żródła oświetlające dzieje kościelne krakowskiej diecezji zawiślańskiej z lat 1772-1785, początki diecezji tarnowskiej, jak również kilka ciekawych źródeł do rabacji z r. 1846.

Równie interesująco przedstawia się biblioteka pokapitulna, wydzielona jako samodzielny zbiór z biblioteki parafialnej. Według ostatniej inwentaryzacji w r. 1954 liczył on 241 tomów a 174 tytuły, w tym 154 tytuly z XVI-XVIII w. Jest to zatem dość pokażny zbiór starodruków. Biblioteka ta nie obejmuje jednak ksiąg liturgicznych z XVI-XVIII w.

Biblioteka powstała przypuszczalnie na początku XVI w. i miała cele praktyczne, mianowicie dostarczanie pomocy duszpasterskich kapłanom pracującym przy kolegiacie. Bardzo mało pozostało śladów przedstawiających troskę o jej całość, zachowanie czy powiększanie zasobów. Dochował się tylko jeden jej inwentarz i to niedatowany, prawdopodobnie z lat osiemdziesiątych XVII w., obejmujący 66 pozy- 
cji ${ }^{29}$. Inwentarz ten wskazuje, że cały szereg dzieł biblioteki nie do. szedł naszych czasów.

W r. 1681 kapituła podjęła uchwałę zalecającą uzupełnienie biblioteki dziełami z zakresu teologii moralnej i kaznodziejstwa ${ }^{30}$. Jak juz wyżej wspomniałem, sporządzony w r. 1776 inwentarz biblioteki nie dochowal się.

Biblioteka kapitulna była przechowywana w skarbcu kolegiackim, v: starych gotyckich murach, w specjalnie na książki sporządzonej 5zafie $^{31}$. Wydaje się, że $w$ drugiej połowie XIX w. została przeniesiona na plebanię, gdzie jednak do dziś nie znalazła właściwego pomieszczenia. Stąd też stan zachowania poszczególnych tomów nie jest zadawalający. Stary papier $w$ wilgotnych pomieszczeniach szybko butwieje i już dzisiaj szereg dzieł jest pozbawiony kart tytułowych, tak że trudno nieraz ustalić, jakie to jest dzieło, a prawie wszystkie tomy są mocno podniszczone przez kornika i wilgoć. Na pewno słuszniejszym byłoby zdeponowanie zbioru w jakiejś większej bibliotece kościelnej, np. w Bibliotece Seminarium Duchownego w Tarnowie, na zasadach depozytu, gdzie książki bez straty dla Wojnicza miałyby zapewnione lepsze warunki zachowaria i wykorzystania.

Zbiór posiada tylko jeden obiekt rękopiśmienny. Jest nim Logika Arystotelesa i Opera phisicorum. Rękopis pochodzi prawdopodobnie z 1606 r. Starodruków z XVI w. posiada zbiór dzieł 16, z XVII w. - 24 a z XVIII - 29. Wśród starodruków jest 11 ksiąg liturgicznych. Przeważają starodruki obce nad polonikami.

Oprócz tego biblioteka zawiera 43 tomy zniszczone do tego stopnia, że jedynie szczególowe studium zawartości mogłoby doprowadzić do rozpoznania ich. W niektórych wypadkach można się domyślać autorstwa względnie daly wydania. Być może, iż znajduje się wśród nich jeszcze kilkanaście wartościowych starodruków a może nawet kilka inkunabułów.

Kończąc opis Archiwum i Biblioteki Parafialnej w Wojniczu (w tym ostatnim wypadku ograniczyliśmy się jedynie do biblioteki pokapitulnej), należy stwierdzić, że aczkolwiek nie zawierają one rewelacyjnych

\footnotetext{
29 Metricae Ecclesiae Collegiatae Voyniciensis. T. I s. 447-448. (Sygn. M/1/1/343. APW).

30 ACV. T. I s. 22.

31 Metricae... T. I s. 449.
} 
zabytków, niemniej znajdują się w nich pozycje, które niewątpliwie dla poznania przeszłości Kościoła polskiego i dla kultury polskiej w wiekach przeszłych nie są bez znaczenia. Szczególnie ciekawe światło rzucają one na ludzi, którzy je gromadzili, troszczyli się o nie i z nich korzystali.

\section{DE ARCHIVO ET BIBLIOTHECA PAROECIALI VOINICIAE}

S u m m a ri u m

roiniciam in rebus Dioeceseos Cracoviensis, deinde Tarnoviensis non mediocres partes habuisse patet. Medio XIII saeculo erat hic decanatus, saeculo vero XV creata est praepositura, postea mutata in collegiatam. Capitulum quod erat in civivtate effecit, ut locuples copiis archivum et non exigua bibliotheca conderentur.

Huic archivo sunt fasciculi (primogenii et descripti) ac libri, quorum ope res gestae Capituli collegialis et paroeciae illustrentur et qui alliciant viros rerum gestarum scientia peritos atque demographos et sociologos. Qui quidem libri magni sunt momenti ad ipsam Voiniciam et generatim omnium rerum ecclesiasticarum memoriam, praesertim quae spectant primordia Dioecesis Tarnoviensis, cognoscendam. Anno 1954 omnia, quae archivo contenta sunt, in singulas digestas partitiones et sec. tiones disposita inventario confecto relata sunt.

Bibliotheca olim Capituli collegialis constat libris vetustioris typographiae (fortasse inveniuntur inter eos pauca difficilius dignoscenda incunabula librorum) tractantibus de theologia dogmatica, morali, iure canonico, historia Ecclesiae, patrologia. Plurima quoque exstant opera sacrae contioni et rei liturgicae destinata. Harum disciplinarum asservata volumina ostendunt usui et solicitudini pastorali ipsa mancipata esse. 